\title{
Persistent organic pollutants in wood fiber-contaminated sediments from the Baltic Sea
}

\author{
Anna-Karin Dahlberg ${ }^{1} \cdot$ Anna Apler $^{2} \cdot$ Lisa Vogel $^{1} \cdot$ Karin Wiberg $^{1} \cdot$ Sarah Josefsson $^{2}$
}

Received: 18 November 2019 / Accepted: 20 March 2020/Published online: 9 April 2020

(C) The Author(s) 2020

\begin{abstract}
Purpose Many coastal areas in the Baltic Sea are contaminated with wood fiber and pollutants from pulp and paper industries. These anthropogenic, organic-rich, sediments (fiberbanks) have not been characterized and knowledge about their role as secondary sources for dispersal of persistent organic pollutants (POPs) is limited. Hence, the aim of this study was to elucidate the fate of POPs and the relationships between sorption $\left(K_{\mathrm{D}}\right.$ and $\left.K_{\mathrm{TOC}}\right)$, sediment type, and compound hydrophobicity $\left(K_{\mathrm{OW}}\right)$ in fiber-contaminated sediments.

Materials and methods Paired sediment and pore water samples $(n=24$ sites) from three fiber-contaminated areas, located in the Ångermanälven river estuary in northern Sweden, were analyzed for POPs (viz. PCBs, DDT, and HCB) in sediment types representing different fiber content (i.e., fiberbanks, fiber-rich sediments, and natural less fiber impacted sediments). The freely dissolved concentration in sediment pore water was determined by sediment-polyoxymethylene (POM) partitioning. Instrumental analysis was performed using gas chromatography coupled to a triple quadrupole mass spectrometer (GC-MS/MS). Results and discussion Higher levels of total organic carbon (TOC) were found in the fiberbank sediment (range 8.6-37\%) than in fiber-rich sediment (range 2.0-6.5\%) and more natural sediment (range 2.0-2.9\%). The sediment concentrations of POPs (dry weight basis) were also found to be significantly $(p<0.05)$ elevated in fiberbanks compared to the other sediment types. The fraction of DDD (48-66\% of $\Sigma_{6}$ DDX) was larger in fiberbanks than in the other sediment types, likely due to anoxic conditions favoring reductive dechlorination of DDT. When sediment levels were normalized to TOC, HCB displayed similar levels across sediment type, suggesting a more diffuse source pattern than for PCB and DDT. Although significantly higher sorption $\left(K_{\mathrm{D}}\right)$ of POPs was observed in fiberbanks, pore water levels were still elevated due to high bulk concentrations.

Conclusions This study shows that fiberbanks are coastal hot spots for POPs in the Baltic Sea and that the levels are of ecotoxicological concern. Although the POPs are more strongly sorbed $\left(K_{\mathrm{D}}\right)$ to this type of organic rich sediment, the high pore water concentrations in fiberbanks compared to the other sediment types investigated show that the risk of contaminant dispersal via pore water is elevated for fiberbanks.
\end{abstract}

Keywords Chlorinated pollutants $\cdot$ Fibrous sediment $\cdot$ Organic carbon $\cdot$ Pore water $\cdot$ Pulp and paper emissions

Responsible editor: Jan Schwarzbauer

Electronic supplementary material The online version of this article (https://doi.org/10.1007/s11368-020-02610-6) contains supplementary material, which is available to authorized users.

Anna-Karin Dahlberg anna.karin.dahlberg@slu.se

1 Department of Aquatic Sciences and Assessment, Swedish University of Agricultural Sciences (SLU), Box 7050, 750 07 Uppsala, Sweden

2 Geological Survey of Sweden (SGU), Box 670, 751 28 Uppsala, Sweden

\section{Introduction}

The Baltic Sea is a brackish semi-enclosed water body in northern Europe. Its large catchment area and the long water residence time make the Baltic Sea susceptible to accumulation of persistent organic pollutants (POPs) (HELCOM 2010). Many of the countries around the Baltic Sea have substantial forest industry with saw mills and pulp and paper production (e.g., Sweden, Finland, Germany, and Poland) (CEPI 2018). These industrial activities have historically been associated with the release of POPs to the environment due to the use of wood preservation products and formation of unwanted by-products 
in the pulp and paper making processes (Ali and Sreekrishnan 2001; Lacorte et al. 2003).

Industrial pulp and paper production started in the late nineteenth century and the industry grew rapidly during the twentieth century. Today, North America and the northern European countries are the dominating pulp producers followed by Asia and Latin America (Suhr et al. 2015; CEPI 2018). During production of pulp, cellulose fibers are separated from other unwanted constituents found in wood (i.e., lignin and hemicellulose) using mechanical or chemical processes. The production of pulp and paper requires large amounts of water, and historically, large quantities of cellulose material were lost and released into the environment with the process wastewater (Ali and Sreekrishnan 2001; Lacorte et al. 2003). In Sweden, it has been estimated that 10.8 million tons of cellulose fiber material was discharged into the aquatic environment between 1908 and 1983 (Swedish-EPA 1995). This fiber material often accumulated on the sea or lake floor and formed large banks of fibers (fiberbanks) in the vicinity of the mills. These anthropogenic sediments are often anoxic, due to the high content of fibrous material and the subsequent high oxygen demand associated with mineralization of organic matter. The fiber material also dispersed and mixed with natural sediment to form so called fiber-rich sediments, which contain less organic matter than the fiberbanks but cover larger areas of the sea or lake floor (Apler et al. 2014). A field survey in coastal areas and inland waters in northern Sweden (see map in Norrlin and Josefsson 2017) resulted in 29 identified fiber sediment areas covering at least $29 \mathrm{~km}^{2}$, and often associated with high levels of POPs.

Fiberbank sediments have been shown to be highly contaminated with heavy metals and POPs, such as polychlorinated biphenyls (PCBs), hexachlorobenzene (HCB), dichlorodiphenyltrichloroethane (DDT), and its transformation products, e.g., dichlorodiphenyldichloroethene (DDE) and dichlorodiphenyldichloroethane (DDD) (Apler et al. 2014, 2019). PCBs were widely deployed in various industrial applications since the late 1920s, including as dielectric fluids in capacitors and transformers, as hydraulic fluids and as lubricants (Erickson and Kaley 2011). Of special relevance for the pulp and paper industry were the use of PCB products as solvents for dyes applied to carbonless copy paper (NCR paper) (Erickson and Kaley 2011), which has led to severe contamination of sediments in the vicinity of pulp mills where recycled PCB-containing paper was used in the production (Bremle et al. 1995). The insecticide DDT was heavily used from the 1940s to control agricultural and forest pests, for example to prevent infestation of the pine weevil (Hylobius abietis) (Farrell 1980). The use of PCBs and DDT was restricted and banned in Sweden and many other countries in the 1970s due to their negative environmental impacts and effects on biota (Helander et al. 2002; Turusov et al. 2002). HCB was introduced as an agricultural pesticide in
1945 and was also used as a fungicide and wood preservative in the forest industry (EFSA 2006), but it is also known to be produced unintentionally in various processes. PCBs, DDT, and HCB were among the first 12 compounds ("the dirty dozen") to be included in the Stockholm Convention on POPs, due to their toxic, persistent, and bioaccumulative behavior in the environment (UNEP 2001).

Sediments act as both sinks and reservoirs for POPs and other hydrophobic contaminants in the aquatic environment due to contaminant sorption to sediment organic matter (Karickhoff et al. 1979). However, as primary sources of legacy POPs have decreased, secondary sources such as leakage from contaminated sediments to the aquatic ecosystem are increasing in importance (Jahnke et al. 2012; Sobek et al. 2014, 2015; Lang et al. 2018). Dispersal of contaminants from sediment can occur via resuspension of sediment particles or via diffusion from sediment pore water to bottom water (Valsaraj et al. 1996). Once freely dissolved, contaminants become available for partitioning to biota, and it has been argued that the potential risks of adverse biological effects of contaminants sorbed to sediments are related to the concentrations in the pore water rather than to total sediment concentrations (Mayer et al. 2014). Nevertheless, national risk classifications of contaminated sediment are still often based on total sediment concentrations. Partitioning of contaminants between sediment and pore water can be expressed by the sediment-specific distribution coefficient, $K_{\mathrm{D}}$ (Birdwell et al. 2007). Since the amount of total organic carbon (TOC) in the sediment is one of the main factors governing the sorption of POPs, organic carbon normalized sediment distribution coefficients $\left(K_{\mathrm{TOC}}\right)$ can be used to describe the equilibrium between sediment TOC and pore water (Birdwell et al. 2007).

Given the threats the legacy POPs still pose to the environment, it is important to identify contaminated sites and assess their environmental risks. Fiberbanks represent a major anthropogenic disturbance on the aquatic environment and habitats. They are a unique type of sediment due to their high content of organic matter, considerably larger than for naturally formed sediments. We have recently investigated the role they play in the fate of metals in the aquatic environment (Apler et al. 2019). However, until now, no other studies have addressed their characteristics as sorbents and their (potential) role as secondary sources for pollution of bioaccumulative and toxic organic compounds to the surrounding aquatic ecosystem. Hence, the aim of this study was to elucidate the fate of selected POPs (PCBs, DDT, and HCB) in fiber-contaminated areas by exploring sorption, pore water concentrations, and pollution patterns. This was done by sampling sediment from fiberbanks, fiber-rich sediments, and less anthropogenically impacted sediments from three areas in the northern Baltic Sea, combined with pore water extractions using polyoxymethylene (POM) strips. 


\section{Materials and methods}

\subsection{Fiberbank areas}

The fiberbank areas studied are located in the Ångermanälven river estuary, in the county of Västernorrland, Sweden (Fig. 1). This region of Sweden has been associated with heavy pulp and paper production since the late nineteenth century, and the selected fiberbanks were chosen based on existing knowledge of the distribution of fiberbanks and land pollution sources in this part of Sweden (Apler et al. 2014). The fiberbank areas studied are located close to Väja kraft pulp mill (V), Sandviken old kraft pulp mill (S), and Kramfors old sulfite pulp mill (K) (Fig. 1; Fig. S1). The selected fiberbanks have previously been characterized by the Geological Survey of Sweden (SGU) using hydroacoustic measurements in combination with sediment sampling (Apler et al. 2014). Sediment accumulation rates at accumulation bottoms located in the vicinity of Väja and Kramfors fiberbanks have been determined to be $0.4 \mathrm{~cm}$ per year using cesium-137 analysis (Apler et al. 2014), but the sedimentation rates at the actual fiberbanks are assumed to have been considerably higher in the past during the periods of emission of fibers from the pulp mills.

The fiberbank in Väja (V) covers $\sim 70,000 \mathrm{~m}^{2}$ and consists mainly of cellulose fibers with a thickness up to $\geq 6 \mathrm{~m}$ at some places. The fiberbank is located at $15 \mathrm{~m}$ water depth and is situated close to a sulfate pulp mill that was established in 1914 (still in production). The factory discarded its cellulose-rich waste water into the river until 1969 when a sedimentation basin was built as an extra clean up step for the waste water (Apler et al. 2014, 2019). The fiberbank in Väja has been reported to be anoxic whereas the fiber-rich sediment, covering $\sim 800,000 \mathrm{~m}^{2}$, is hypoxic (Apler et al. 2014, 2019).

The fiberbank in Sandviken (S) is less extensive, $\sim 55,000 \mathrm{~m}^{2}$, and consists mainly of wood fibers and wood chips, with a thickness up to $\geq 6 \mathrm{~m}$ at some places. The fiberbank is located at $12 \mathrm{~m}$ water depth and is situated close to a former industrial site where a sulfate pulp mill was operating between 1929 and 1979. After closing down, the factory was demolished and discarded on site (Apler et al. 2014,

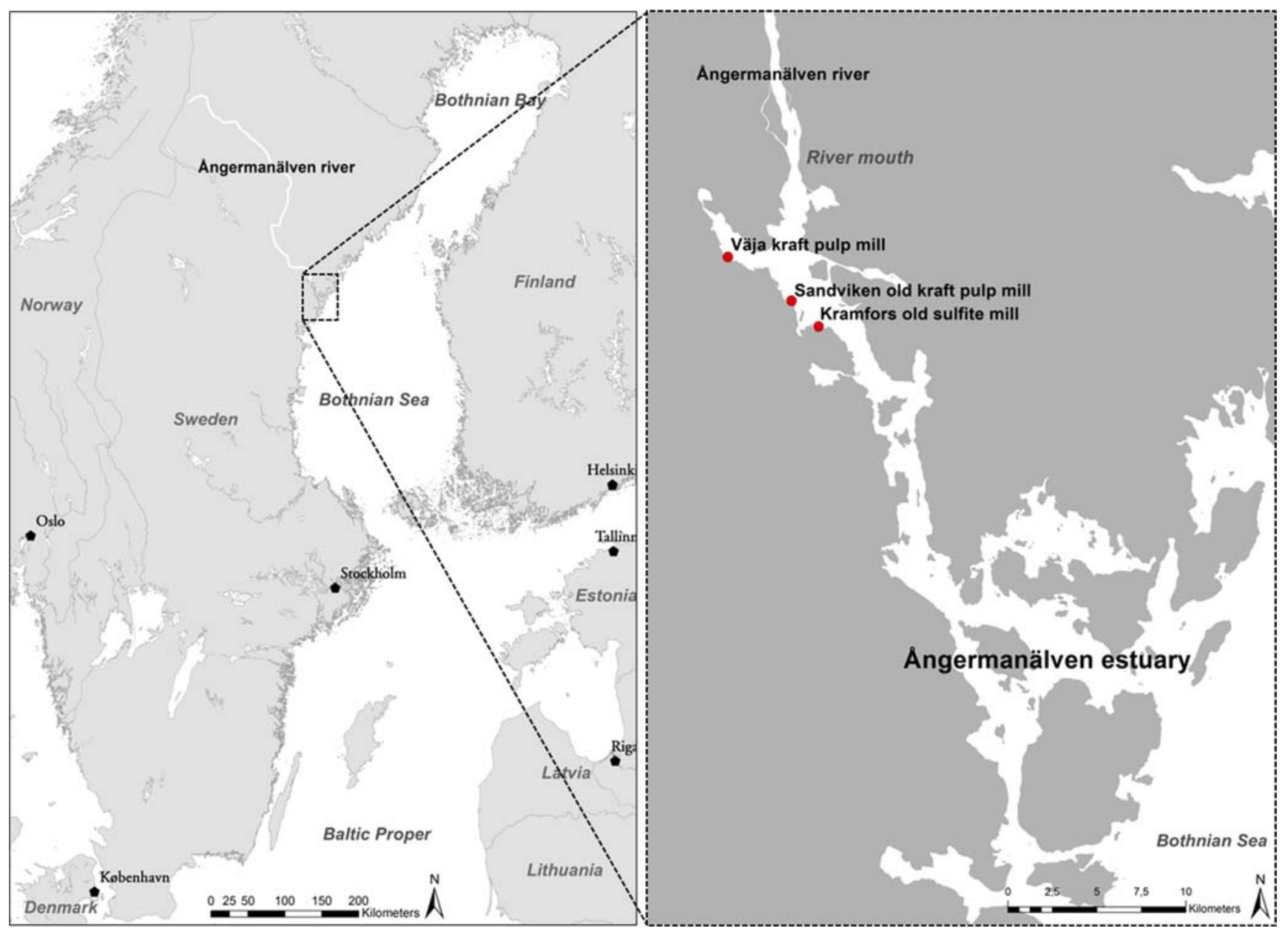

Fig. 1 Ångermanälven River estuary (Sweden) with the three fiberbank areas indicated 
2019). The fiberbank in Sandviken, as well as the $\sim 500,000 \mathrm{~m}^{2}$ fiber-rich sediment, has been reported to be hypoxic (Apler et al. 2014, 2019).

The fiberbank in Kramfors $(\mathrm{K})$ covers $\sim 135,000 \mathrm{~m}^{2}$ and is also $\geq 6 \mathrm{~m}$ thick. It is situated close to a former industrial site where a sulfite pulp mill was operating between 1907 and 1977. Until closure, the factory discarded its waste water containing wood fibers and wood shavings into the river, and it has been estimated that 25 tons of wood fibers and wood shavings were released per day from the factory (Apler et al. 2014).

\subsection{Sediment samples}

Surface sediment samples ( $n=24$ sites) were collected from fiberbanks $(n=9)$, fiber-rich sediments $(n=11)$, and less anthropogenically impacted sediments ( $n=4$; referred to as "natural sediments") (Fig. S1) during the summer seasons of 2014 and 2015. Fiberbanks are defined as containing almost only organic matter, while fiber-rich sediments consist to a larger extent of natural sediments, mixed with wood fibers. The natural, more minerogenic sediment further away from the fiberbanks, usually postglacial clays, also contains organic carbon (approx. 2-3\% of dry weight) but with no visible signs of fibers. The sampling was performed from SGU's research vessel S/V Ocean Surveyor using a Gemini core sampler (GEMAX), an Orange Peel Bucket (OPB) sampler or a box corer sampler. Detailed sampling information is found in supporting information (Table S1). The sampling was mainly performed with the GEMAX sampler, collecting sediment at $0-4 \mathrm{~cm}$ depth $(n=15)$. Due to the soft nature of the fiberbank sediment (not allowing retrieval of intact cores), the OPB or box corer sampler had to be used occasionally. In these cases, the sampling depth was $0-40 \mathrm{~cm}(\mathrm{OPB}, n=7)$ and $0-30 \mathrm{~cm}$ (box corer, $n=2$ ). This means that the covered time frame of sedimentation varies between samples; however, the sediment accumulation rate at the fiberbanks is likely to have varied substantially over time as well as between the different areas due to the production volumes and release of fibers. Since the sediment and pore water samples are aliquots of the same sample, partitioning between sediment and pore water can be compared between samples despite varying sampling depth. The consistency of the sediment samples collected using OPB and box corer was loose and without obvious layering. To obtain representative samples from these bulk samples, several subsamples were taken and combined in glass jars. Each sediment sample was then mixed thoroughly to make it as homogenous as possible before withdrawal for analyses. The samples were stored cold $\left(+4{ }^{\circ} \mathrm{C}\right)$ prior to sediment pore water extraction and then frozen $\left(-18{ }^{\circ} \mathrm{C}\right)$ until chemical analysis.

\subsection{Sediment organic carbon}

An aliquot of each sediment sample was heated to $105^{\circ} \mathrm{C}$ for $24 \mathrm{~h}$ for gravimetrical determination of dry weight ( $\mathrm{dw}$ ). The total carbon (TC) and total organic carbon (TOC) contents of the sediment were determined by dry combustion $\left(1350{ }^{\circ} \mathrm{C}\right)$ and elemental analysis using a TruMac instrument (Leco Corporation, St Joseph, USA) following the Swedish standard procedure SS-ISO 10694.

\subsection{Target compounds}

Twenty polychlorinated biphenyls (PCBs) were included in the analysis; four planar (non-ortho substituted) congeners (CBs $-77,-81,-126,-169$ ), eight coplanar (mono-ortho substituted) congeners (CBs $-105,-114,-118,-123,-$ $156,-157,-167,-189)$, and eight non-planar congeners (CBs - 28, - 52, - 101, - 138, - 153, - 170, - 180,-209). In the following, the sum of all target PCBs are abbreviated $\Sigma_{20} \mathrm{PCBs}$, while the sum of the seven indicator PCBs (CBs $28,-52,-101,-118,-138,-153,-180)$ are presented as $\Sigma_{7}$ PCBs. In addition, hexachlorobenzene (HCB), dichlorodiphenyltrichloroethane $\left(o, p^{\prime}\right.$-DDT and $p, p^{\prime}$-DDT) and their transformation products dichlorodiphenyldichloroethene $\left(o, p^{\prime}\right.$-DDE, $p, p^{\prime}$-DDE) and dichlorodiphenyldichloroethane $\left(o, p^{\prime}\right.$-DDD, $p, p^{\prime}$-DDD) were analyzed. The sum of the six DDT-related compounds is abbreviated $\Sigma_{6} \mathrm{DDX}$. The origin of authentic reference compounds, isotope- $\left({ }^{13} \mathrm{C}\right)$-labeled internal standards, and isotope- $\left({ }^{13} \mathrm{C}\right)$-labeled recovery standards is given in the supporting information together with their full names and abbreviations (Tables S2 and S3).

\subsection{Sediment-POM partitioning for pore water determination}

Polyoxymethylene (POM) strips were used to determine the freely dissolved concentrations of POPs in sediment pore water ( $n=24$ sites), based on the method by Hawthorne et al. (2009), where a POM strip is shaken for 28 days in a sediment-water slurry and the POPs equilibrate and distribute to the POM. After analysis of the POP concentrations in the $\mathrm{POM}$, the equilibrium concentrations of the freely dissolved POPs in the pore water can be determined using established POM-water partitioning coefficients $\left(K_{\mathrm{POM}}\right)$ for the specific POM-type (see Sect. 2.9 for calculations).

Before use, the POM strips ( $76 \mu \mathrm{m}$ in thickness, CS Hyde, Lake Villa, IL, USA) were soaked in acetone $/ n$-hexane $(1: 1$, $v / v$ ), followed by methanol for $2 \times 24 \mathrm{~h}$, respectively. The clean POM strips were then rinsed with Millipore water and stored dried in a sealed glass jar before use. Sediment (20$30 \mathrm{~g}$ wet weight) was transferred to amber glass jars $(40 \mathrm{~mL})$. Pre-cleaned POM strips with the dimensions $2 \mathrm{~cm} \times 3 \mathrm{~cm} \times$ $76 \mu \mathrm{m}$ were used in year 2014. However, the size of the POM 
strips was reduced $(1 \mathrm{~cm} \times 1.5 \mathrm{~cm} \times 76 \mu \mathrm{m}$ thick $)$ in year 2015 to comply with the depletion criteria described in the section below. A POM strip was placed in each jar, and Millipore water with $1 \mathrm{mM} \mathrm{CaCl}_{2}$ and $15 \mathrm{mM} \mathrm{NaN}_{3}$ (to correspond to Swedish leaching test standards) was added to fill each jar, leaving only a small head space. Five of the 24 sediment samples were analyzed in triplicate to check the method variability, whereas the rest of the samples $(n=19)$ was analyzed as single samples. Thus, in total, 34 POM samples were analyzed. Procedural solvent blanks ( $n=6$, identical sample preparation as sediment samples but without sediment) were also included for quality assurance. Each sample was shaken at room temperature for 28 days using an end-over-end shaker to reach equilibrium. After partitioning, the POM strips were retrieved, wiped clean from sediment particles, and extracted as described below.

During POM partitioning, the amount of POPs taken up by the POM should not exceed $5 \%$ of the total amount of POPs sorbed to the sediment to ensure that the equilibrium is not distorted (Mayer et al. 2014). In the samples collected in 2014, this depletion criteria was not met; however, the difference between sediment sorption coefficient $\left(K_{\mathrm{D}}\right)$ values calculated before and after correcting for depletion were negligible and these samples were also included in the data evaluation (see Sect. 3.4). The size of the POM strip was, as mentioned, reduced for the samples collected in 2015 to comply with the depletion criteria of $5 \%$.

\subsection{Extraction and clean-up of POM and sediment}

Sediment samples ( $n=24$ sites) were extracted using Soxhlet, based on US EPA method 3540C (US-EPA 1996). Four sediment samples were extracted and cleaned up in triplicate, whereas the rest of the samples $(n=20)$ were analyzed as single samples. Thus, in total, 32 sediment samples were analyzed. Procedural solvent blanks $(n=6)$ were also included for quality assurance. Prior to extraction, each sediment sample (5 g) was mixed with sodium sulfate $\left(\mathrm{Na}_{2} \mathrm{SO}_{4}, 50 \mathrm{~g}\right)$ and spiked with isotope- $\left({ }^{13} \mathrm{C}\right)$-labeled internal standards. For some samples with high water content, $10 \mathrm{~g}$ of sediment and $100 \mathrm{~g}$ sodium sulfate $\left(\mathrm{Na}_{2} \mathrm{SO}_{4}\right)$ was used instead. Soxhlet extraction was carried out with acetone $/ n$-hexane $(225 \mathrm{~mL}, 1: 1, v / v)$ for approximately $24 \mathrm{~h}$. After extraction, copper activated with hydrochloric acid $(\mathrm{HCl})$ was added to remove sulfur. The extracts were cleaned up on multilayer columns composed of activated silica $\left(\mathrm{SiO}_{2}, 3 \mathrm{~g}\right)$, sulfuric acid-treated silica $\left(40 \% \mathrm{H}_{2} \mathrm{SO}_{4} / \mathrm{SiO}_{2}, 6 \mathrm{~g}\right)$, and sodium sulfate $\left(\mathrm{Na}_{2} \mathrm{SO}_{4}, 3 \mathrm{~g}\right)$, similar to Josefsson et al. (2010). The analytes were eluted with $n$-hexane $(60 \mathrm{~mL})$. Isotope- $\left({ }^{13} \mathrm{C}\right)$-labeled recovery standards were added and the sample volume was reduced to $100 \mu \mathrm{L}$ of $n$-tetradecane.

Each POM strip was extracted with acetone/n-hexane (1:1, $v / v, 20+20 \mathrm{~mL}$ ) for $2 \times 24 \mathrm{~h}$ using an end-over-end shaker.
Prior to extraction, isotope- $\left({ }^{13} \mathrm{C}\right)$-labeled internal standards were added. After extraction, the POM strip was retrieved and the weight of the dry POM strip was determined gravimetrically. Isotope- $\left({ }^{13} \mathrm{C}\right)$-labeled recovery standards were added to the extract and the sample volume was reduced to $100 \mu \mathrm{L}$ of $n$-tetradecane.

All chemicals and solvents used were of the highest purity available as described in supporting information.

\subsection{Instrumental analysis}

The instrumental analysis was performed using a gas chromatograph (GC; Agilent Technologies, 7890 A) coupled to a triple quadrupole mass spectrometer (Agilent Technologies, 7010, GC-MS/MS Triple Quad). The analysis was carried out using multiple reaction monitoring (MRM) mode, monitoring two transitions for each target compound. Details on the instrumental settings are presented in Table S4 in the supporting information, where also details on the MRM ions are given. Identification and quantification were performed using authentic reference standards. For data evaluation, the software Agilent MassHunter Quantitative Analysis (for QQQ) was used.

\subsection{QA/QC}

The use of isotope- $\left({ }^{13} \mathrm{C}\right)$-labeled surrogate standards corrected for losses during sample extraction and clean up. The recovery of the surrogate standards was on average $93 \pm 18 \%$ for $\mathrm{PCBs}, 99 \pm 22 \%$ for $\mathrm{HCB}$, and $97 \pm 16 \%$ for DDX in sediment. In POM, the recovery of the surrogate standards was on average $107 \pm 12 \%$ for $\mathrm{PCBs}, 114 \pm 19 \%$ for $\mathrm{HCB}$, and $105 \pm 18 \%$ for DDX. The limit of detection (LOD) was set as the signal-to-noise ratio of 3 . The limit of quantification (LOQ) was set to the lowest calibration solution that could be detected reliably by the GC-MS/MS. Blanks generally showed little or no contamination but average blank levels were subtracted from samples if present. Blank contamination was noted for $\mathrm{HCB}$ in pore water samples collected 2015, where the levels in sedimentexposed POM were similar to levels in blank POMs. Due to this, HCB pore water concentrations obtained from the sampling campaign in 2015 were excluded from the data evaluation.

The four triplicate sediment samples showed low method variability with average relative standard deviations (RSDs) of $11 \%\left(\Sigma_{20} \mathrm{PCBs}\right), 16 \%$ (HCB), and $15 \%$ ( $\left.\Sigma_{6} \mathrm{DDX}\right)$. Similar variability was obtained for the five triplicate pore water (POM) samples with average RSDs of $6.3 \%\left(\Sigma_{20} \mathrm{PCBs}\right)$, $16 \%$ (HCB), and $11 \%\left(\Sigma_{6} \mathrm{DDX}\right)$. 


\subsection{Calculations}

The sediment pore water concentration $\left(C_{\mathrm{pw}}\right)$ of each target compound was calculated using the measured concentrations in POM $\left(C_{\mathrm{POM}}\right)$ and established POM-water partitioning coefficients $\left(K_{\mathrm{POM}}\right)$ for PCBs (Hawthorne et al. 2009), HCB (Endo et al. 2011), and DDX (Endo et al. 2011) (Eq. (1)). The $K_{\mathrm{POM}}$ values used for each compound are listed in supporting information, Table S2.

$C_{\mathrm{pw}}=C_{\mathrm{POM}} / K_{\mathrm{POM}}\left(\right.$ unit $\left.: \mathrm{pg} \mathrm{L}^{-1}\right)$

Sediment sorption coefficient $\left(K_{\mathrm{D}}\right)$ for each target compound was calculated (Eq. (2)) based on the measured pore water concentration $\left(C_{\mathrm{pw}}\right)$ and sediment concentration $\left(C_{\mathrm{SED}}\right)$ normalized to sediment dry weight $(\mathrm{dw})$.

$K_{\mathrm{D}}=C_{\mathrm{SED}} / C_{\mathrm{pw}}\left(\right.$ unit $\left.: \mathrm{L}_{\mathrm{pw}} \mathrm{kg}_{\mathrm{dw}}{ }^{-1}\right)$

Since sorption of hydrophobic organic contaminants occurs mainly by partitioning to organic matter, the organic carbon normalized sorption $\left(K_{\mathrm{TOC}}\right)$ coefficient was calculated for each target compound by using the fractional amount of organic carbon $\left(f_{\text {TOC }}\right)$ in sediment, as described in Eq. (3).

$K_{\mathrm{TOC}}=K_{\mathrm{D}} / f_{\mathrm{TOC}}\left(\right.$ unit : $\left.\mathrm{L}_{\mathrm{pw}} \mathrm{kg}_{\mathrm{OC}}{ }^{-1}\right)$

\subsection{Statistical analysis}

For statistical analysis and calculations of geometric mean (GM) and sum, values below LOQ were assigned a value of $L O Q / 2$. One-way ANOVA was used to test for significant differences between groups of samples. Principal component analysis (PCA) was performed to explore differences in sediment pollution pattern between sediment types (fiberbank, fiber-rich sediment, and natural sediment) and sampling area (Väja, Sandviken, and Kramfors) using the statistical software SIMCA version 14.0.0.1359 (Umetrics, Umeå, Sweden). The PCAs were performed based on the concentration of each substance relative to the sum of each compound class (i.e., normalized values, fractions). To explore potential sources for the PCBs, a cluster analysis (Ward's method) was used to group sediment samples by their relative concentration of PCB congeners ( $\%$ of $\left.\Sigma_{20} \mathrm{PCBs}\right)$ together with literature data for 12 technical $\mathrm{PCB}$ products (\% of $\Sigma_{20} \mathrm{PCBs}$ ) (Schulz et al. 1989; Kim et al. 2004). The cluster analysis was also performed using the statistical software SIMCA version 14.0.0.1359 (Umetrics, Umeå, Sweden).

\section{Results and discussion}

\subsection{Sediment characteristics}

The amount of TOC was substantially higher in fiberbank sediment (range 8.6-37\%) than in fiber-rich sediment (range 2.0-6.5\%) and natural clay sediment (range 2.0-2.9\%) (Fig. $\mathrm{S} 2$ ). The TOC content is related to fiber impact, as the accumulated fiber material, which makes up the fiberbanks, consists of organic material (i.e., cellulose, wood fibers, and wood shavings) released from saw mills and pulp and paper factories in the past. In Väja (V) and Kramfors (K), the fiberbank samples contained cellulose fibers, whereas deposits in Sandviken (S) contained mainly wood splinters and chips.

The classification of samples into the sediment types was based on SGU's existing maps of the spatial distribution of fiberbanks and fiber-rich sediments in the three areas (Fig. S1). However, the boundaries between fiberbank and fiberrich sediments are not fully established and two samples (Väja, V8 and Kramfors, K4), which were sampled within the estimated area of the fiberbank, had to be re-classified as fiber-rich sediments as their organic carbon contents (4.4 and $2.5 \%$ TOC) were more similar to the other fiber-rich sediment samples in the same area (Table S1).

\subsection{Sediment concentrations}

The average (geometric mean (GM); ng g ${ }^{-1} \mathrm{dw}$ ) sediment concentrations of $\Sigma_{7} \mathrm{PCBs}, \Sigma_{20} \mathrm{PCBs}, \Sigma_{6} \mathrm{DDX}$, and HCB are illustrated in Fig. 2a-c, while maximum, minimum, and GM concentrations of individual compounds (and sum parameters) of PCBs, DDX, and HCB in the different sediment types are presented in Tables S5-S7 in the supporting information. The fiberbanks contained significantly $(p<0.05)$ higher levels of $\Sigma_{20} \mathrm{PCBs}, \Sigma_{6} \mathrm{DDX}$, and HCB than fiber-rich sediment and natural sediments. The average concentration of $\Sigma_{7} \mathrm{PCBs}$ in the fiberbank in Sandviken ( $37 \mathrm{ng} \mathrm{g}^{-1} \mathrm{dw}$ ) is higher than in Kramfors (30 ng g ${ }^{-1} \mathrm{dw}$ ) or Väja $\left(25 \mathrm{ng} \mathrm{g}^{-1} \mathrm{dw}\right)$, and the concentrations are classified as high level (category IV) or very high level (category V) according to the Swedish environmental assessment criteria for organic pollutants in sediment (Josefsson 2017). These assessment criteria are based on the statistical distribution of concentrations in Swedish sediments, not ecotoxicological effects, with the border between category III and IV at the 75th percentile and the border between category IV and $\mathrm{V}$ at the 95th percentile.

The average (GM) concentration of $\Sigma_{3} p, p^{\prime}$-DDX is also higher in the fiberbank in Sandviken $\left(6.2 \mathrm{ng} \mathrm{g}^{-1} \mathrm{dw}\right)$ than in Väja (2.4 $\left.\mathrm{ng} \mathrm{g}^{-1} \mathrm{dw}\right)$ and Kramfors (1.7 $\left.\mathrm{ng} \mathrm{g}^{-1} \mathrm{dw}\right)$, and levels are classified as high (IV) or moderate (III) according to the Swedish assessment criteria (Josefsson 2017). The average (GM) concentrations of HCB, on the other hand, are lower in the fiberbank in Sandviken $\left(0.46 \mathrm{ng} \mathrm{g}^{-1} \mathrm{dw}\right)$ than in Väja 


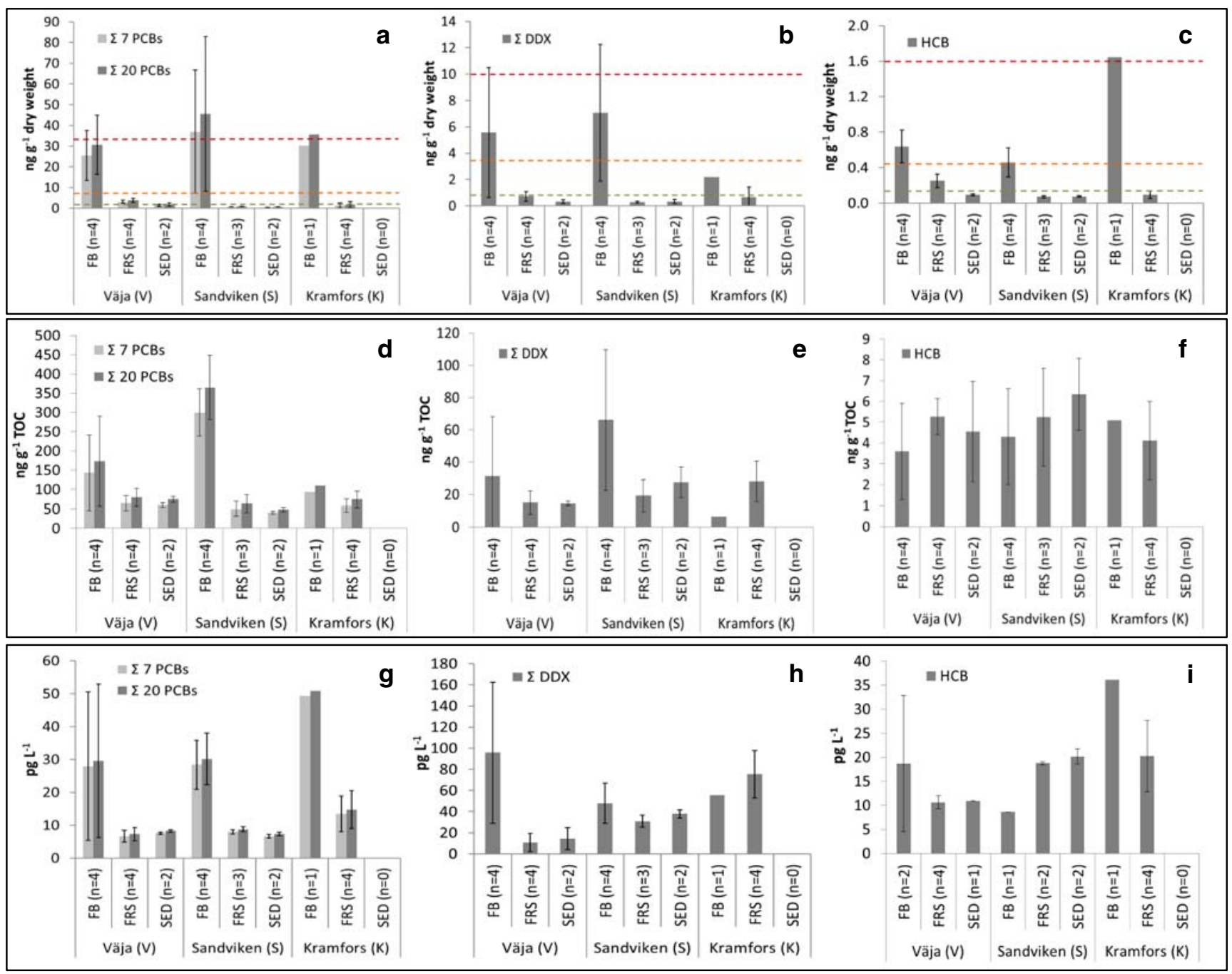

Fig. 2 Levels of $\Sigma_{7} \mathrm{PCBs}$ and $\Sigma_{20} \mathrm{PCBs}, \Sigma_{6} \mathrm{DDX}$ and $\mathrm{HCB}$ in a-f sediment and $\mathbf{g}-\mathbf{i}$ pore water in fiberbank (FB), fiber-rich sediment (FRS), and natural sediments (marked "sediment", SED) sampled in different areas (Väja, Sandviken, Kramfors). Sediment concentrations are normalized to sediment dry weight ( $\mathrm{ng} \mathrm{g}^{-1}$ dry weight) (a-c) and total organic carbon (ng g ${ }^{-1}$ TOC) $(\mathbf{d}-\mathbf{f})$. Pore water concentrations are

(0.64 $\mathrm{ng} \mathrm{g}^{-1} \mathrm{dw}$ ), whereas the only sample from Kramfors contained $1.6 \mathrm{ng} \mathrm{g}^{-1} \mathrm{dw}$ of HCB. These levels are classified as category IV and $\mathrm{V}$, according to the aforementioned quality criteria (Josefsson 2017).

When the POP concentrations were normalized to the sediment TOC, the concentration differences between sediment types became less pronounced (Fig. $2 \mathrm{~d}-\mathrm{f}$ ). This is expected, due to the higher content of TOC in the fiberbanks compared to fiber-rich sediments and natural sediments (Fig. S2). However, the levels of PCBs (in Sandviken and Väja) and DDX (in Sandviken) were still significantly $(p<0.05)$ elevated in the fiberbanks compared to fiber-rich sediments and natural sediments. If the pollution was a result of diffuse pollution (e.g., atmospheric deposition) in the water body, the expressed in pg L $\mathrm{L}^{-1}(\mathbf{g}-\mathbf{i})$. Data is presented as geometric mean and error bars show the standard deviation for $n$ number of samples. In a-c, the dotted lines indicate the Swedish environmental assessment criteria for moderate levels (category III, green), high levels (category IV, yellow), and very high levels (category $\mathrm{V}$, red) for $\Sigma_{7} \mathrm{PCBs}, \Sigma_{3} \mathrm{DDX}$, and HCB, respectively

sediment concentration normalized to TOC are expected to be more even, analogous to the case for POPs in soil (Meijer et al. 2003). Our results therefore show that the source of pollution is of local origin and not a result of diffuse pollution. For DDX, the Kramfors area was deviating from Väja and Sandviken, in that the concentrations were lower in the fiberbank than in the fiber-rich sediment on a TOC-basis (Fig. 2e). However, the single fiberbank sample collected in Kramfors is insufficient for statistical evaluation of the result and furthermore, had a very high TOC content (37\%). For $\mathrm{HCB}$, the TOC-normalized concentrations were more similar across sediment types and sites (Fig. 2f), indicating that diffuse pollution plays a more important role for this compound in the study area. 


\subsection{Sediment pollution pattern}

The relative distribution of individual PCBs and DDX in sediment is presented in Fig. 3a, b, and as PCA biplots in Fig. S3S4. PCBs were used as technical PCB mixtures containing a large number of congeners with different degree of chlorination. The sediment congener profile is dominated by CB-138, CB-153, and CB-101, together comprising up to $49-64 \%$ of $\Sigma_{20} \mathrm{PCBs}$ in all sediment types investigated. To further evaluate the PCB patterns, a cluster analysis of the congener patterns was performed including 12 historically commercial technical PCB products. Although the PCB pattern in the fiberbanks may have altered compared to the technical product due to aging (related to, e.g., differences in physicochemical properties and persistence among congeners), the vicinity of the fiberbanks to the source (pulp and paper mill) and the strong sorption to the organic material still makes it possible that the original product congener pattern is reflected in the sediment. The cluster analysis showed five clusters (Fig. 4) in which Sandviken (S1-S4) clustered together with Kanechlor KC500, while fiberbank samples from Kramfors (K1) and Väja (V1-V4) clustered with three technical PCB products Clophen A60, Aroclor 1260, and Kanechlor KC600. Hence, the results from the PCA and cluster analysis indicate the use of different PCB products in the past in Sandviken

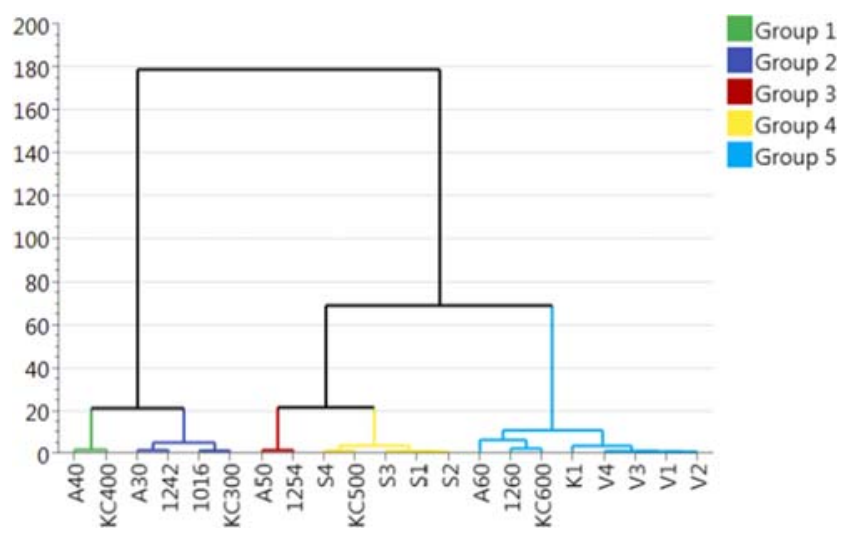

Fig. 4 Cluster analysis of normalized PCB concentrations (\% of $\Sigma_{20} \mathrm{PCBs}$ ) in fiberbank sediments from Väja (V1-V4), Sandviken (S1S4), Kramfors (K1), and 12 commercial PCB products (Aroclor 1016, Aroclor, 1242, Aroclor 1254, Aroclor 1260, Clophen A30, Clophen A40, Clophen A50, Clophen A60, Kanechlor KC300, Kanechlor KC400, Kanechlor KC500, and Kanechlor KC600) with different PCB congener composition (Schulz et al. 1989; Kim et al. 2004). Five clusters were obtained and are colored according to group

compared to Väja and Kramfors and that this is still reflected in the sediment today even though the contamination occurred decades ago (e.g., Sandviken closing down around 40 years ago).

For DDT and its transformation products DDE and DDD, the compound profiles in the three fiberbanks were dominated
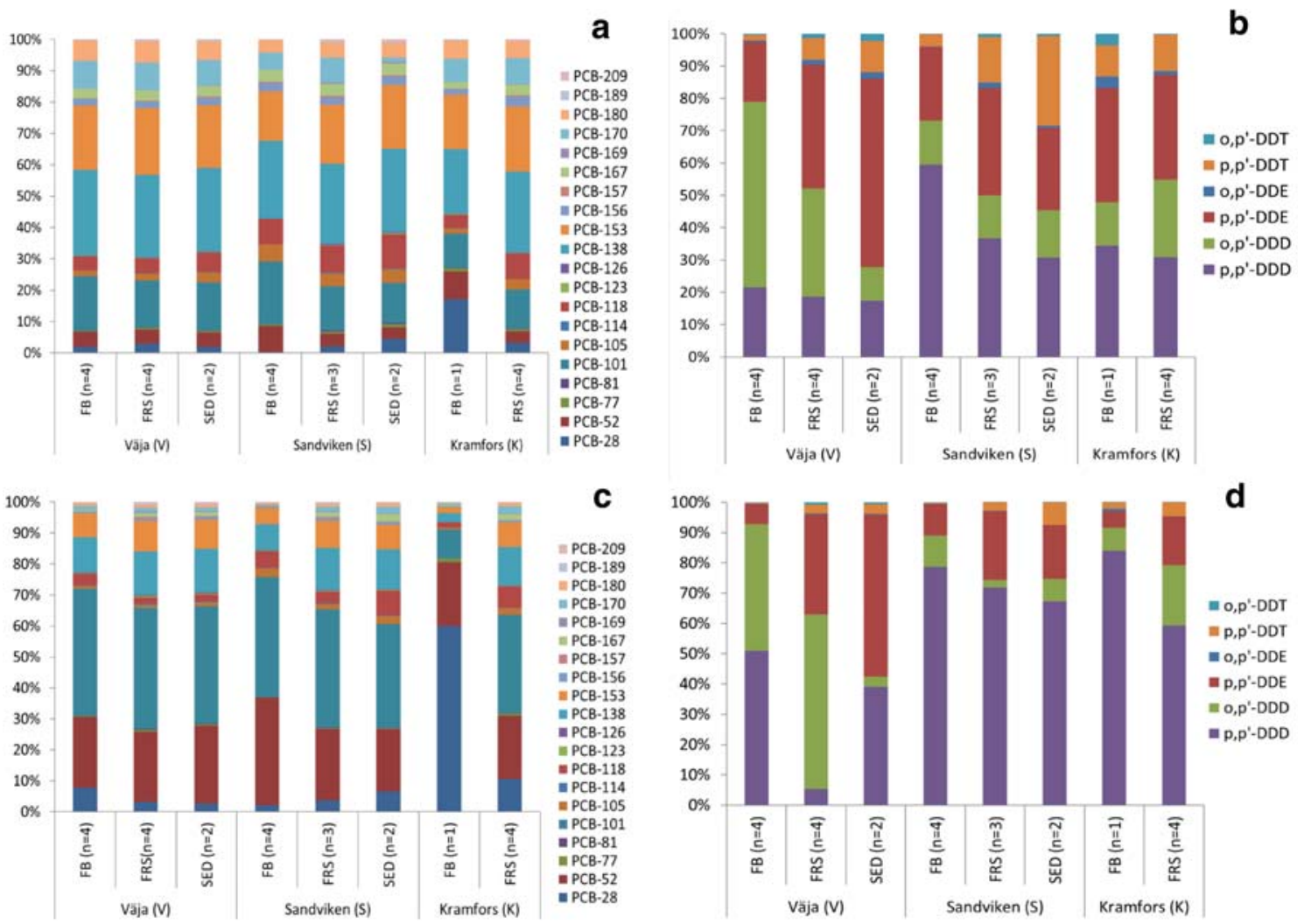

Fig. 3 Relative distribution of individual PCBs ( $\%$ of $\left.\Sigma_{20} \mathrm{PCBs}\right)$ and DDX ( $\%$ of $\left.\Sigma_{6} \mathrm{DDX}\right)$ in $\mathbf{a}, \mathbf{b}$ fiberbank sediment and $\mathbf{c}, \mathbf{d}$ in pore water from Väja (V), Sandviken (S), and Kramfors (K) 
by DDD (48-66\%) followed by DDE (16-39\%), whereas DDT constituted only a smaller part (2-13\%) (Fig. 3b). The predominance of transformation products over DDT reflects that long time has passed since DDT was in use at these three sites. The fraction of DDD was larger in fiberbanks than in fiber-rich sediment and natural sediment in Väja and Sandviken (Fig. 3b), which likely reflects the anoxic conditions in the fiberbanks. DDT mainly undergo reductive dechlorination to form DDD under anoxic conditions, whereas dehydrochlorination of DDT to yield DDE is the main reaction during aerobic conditions (Aislabie et al. 1997). Because the fiberbanks contain exceptionally large amounts of organic matter, the oxygen in the sediment is completely consumed when the matter is degraded, leading to anoxic conditions also at the sediment surface and gas formation (as observed in field). In the fiber-rich sediment, however, the sediment surface may have oxidizing conditions, resulting in less DDD formation and a larger fraction of DDE. The difference in oxygen conditions in fiber-rich sediment compared to fiberbanks was also demonstrated by the presence of benthic biota in the fiber-rich sediment in contrast to the fiberbanks, where no biota was found.

As for the PCBs, the DDX compound profiles indicate usage of different DDT-containing products at the different sites. In Sandviken and Kramfors, $p, p^{\prime}$-DDD dominated over $o, p^{\prime}$-DDD as expected after past use of DDT (Fig. 3b), whereas in both the fiberbank and the fiber-rich sediment in Väja, the concentrations of $o, p^{\prime}$-DDD were higher than of $p, p^{\prime}$-DDD (Fig. 3b). This could potentially be related to use of Dicofol, which is synthesized from technical DDT and contains on average of $11 \% o, p^{\prime}$-DDT and $1.7 \% p, p^{\prime}$-DDT (Qiu et al. 2005; Wong et al. 2009).

\subsection{Freely dissolved concentrations in sediment pore water}

Sediment pore water concentrations $\left(\mathrm{pg} \mathrm{L}^{-1}\right)$ of PCB, DDX, and $\mathrm{HCB}$ are presented in Fig. 2g-i and Tables S8-S10 in the supporting information. As mentioned, the samples collected in 2014 did not comply with the depletion criteria of 5\% when sampled. This can potentially have affected the equilibrium resulting in underestimation of the freely dissolved concentrations in these samples (Mayer et al. 2003). However, a comparison between the measured pore water concentrations collected 2014 and 2015 shows that the concentrations are well correlated (Pearson $p<0.05$ ) for both $\Sigma_{20} \mathrm{PCBs}$ and $\Sigma_{6} \mathrm{DDX}$ between sampling years (Fig. S5).

Previous studies that measured freely dissolved pore water concentration of POPs in sediment from the Baltic Sea have focused on PCBs and dioxins (Cornelissen et al. 2008; Jahnke et al. 2012; Sobek et al. 2014; Lang et al. 2018). The geometric mean $(\mathrm{GM})$ concentrations of $\Sigma_{7} \mathrm{PCBs}$ in the fiberbank samples from Väja (28 pg L $\left.{ }^{-1}\right)$, Sandviken $\left(28 \mathrm{pg} \mathrm{L}^{-1}\right)$, and
Kramfors ( $49 \mathrm{pg} \mathrm{L}^{-1}$ ) were approximately 10 times lower than those found in pore water from contaminated accumulation sediments from Stockholm harbor (Jahnke et al. 2012), but similar to what was found in the Stockholm archipelago (Jahnke et al. 2012) and other contaminated areas of the Baltic Sea (Lang et al. 2018). Even lower values of $\Sigma_{7}$ PCBs have been reported for the open Baltic Sea, with values ranging from 1.9 to $10 \mathrm{pg} \mathrm{L}^{-1}$ (Cornelissen et al. 2008).

Concentrations of DDX in pore water of Baltic Sea sediments are, to the best of our knowledge, presented for the first time here. Our results show that the pore water concentrations of $\Sigma_{6} \mathrm{DDX}$ in fiberbanks can exceed the levels of PCBs (Fig. $2 \mathrm{~g}-\mathrm{h}$ ), even though total sediment concentrations are lower for $\Sigma_{6} \mathrm{DDX}$ than for PCBs. As shown by $K_{\mathrm{OW}}$ (Table S2), DDXs $\left(\log K_{\mathrm{OW}} 5.5-7.0\right)$ are generally less hydrophobic than PCBs ( $\left.\log K_{\mathrm{OW}} 6.4-8.2\right)$ and therefore less tightly sorbed to the organic carbon-rich material in the fiberbanks. Therefore, the relatively high concentrations of DDX in the pore water are reasonable. However, this comparison might be biased by the inclusion of many of the more hydrophobic PCB congeners (e.g., penta- through deca-CBs) in the analyses in the present study in favor of more water soluble ones (e.g., triand tetra-CBs).

The relative distribution of individual PCBs and DDX in pore water is presented in Fig. 3c, d. The PCB congener profile was dominated by CB-52 and CB-101, together comprising up to $52-72 \%$ of $\Sigma_{20}$ PCBs. An exception to this pattern was the fiberbank pore water from Kramfors, which was dominated by CB-28 (60\%). This agrees with this fiberbank sample also containing a higher proportion of CB-28 in the sediment than the other sediment types investigated (Fig. 3a). The predominance of less chlorinated PCBs in pore water is expected since they are less hydrophobic than the more chlorinated (heavier) PCBs. It is also apparent that $p, p^{\prime}-\mathrm{DDD}$, which is the compound with the lowest hydrophobicity of the $\Sigma_{6} \mathrm{DDX}$, has an increased proportion in pore water compared to sediment (Fig. 3d).

\subsection{Sediment sorption}

The type and amount of organic material in the sediment affect the compounds' degree of sorption to sediment and thus also the extent of their bioavailability. To investigate if the sorption differed between sediment types, the distribution coefficient normalized to sediment dry weight $\left(K_{\mathrm{D}}\right)$ and sediment organic carbon $\left(K_{\mathrm{TOC}}\right)$ was calculated (Fig. 5). When combining data from Väja, Sandviken, and Kramfors, the average sorption of POPs was found to be significantly higher (one-way ANOVA, $p<0.05)$ in fiberbank $\left(\log K_{\mathrm{D}} 5.9\right)$ compared to fiber-rich sediment $\left(\log K_{\mathrm{D}} 5.0\right)$ (Fig. S6A). However, no significant difference was observed between fiber-rich sediment and natural sediment $\left(\log K_{\mathrm{D}} 4.8\right)$. The higher sorption $\left(K_{\mathrm{D}}\right)$ in fiberbanks means that a smaller fraction of the sediment 


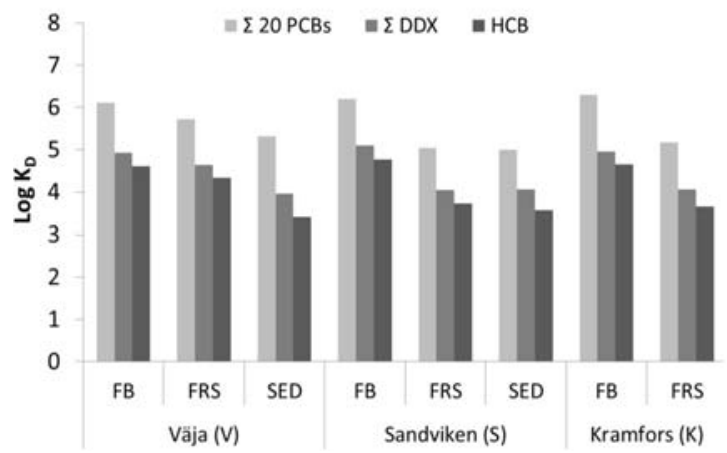

Fig. 5 Sorption normalized to sediment dry weight $\left(\log K_{\mathrm{D}}\right)$ and sediment organic carbon $\left(\log K_{\mathrm{TOC}}\right)$ in fiberbank (FB), fiber-rich sediment (FRS), and natural sediments (SED) from Väja (V), Sandviken (S),

contaminants was bioavailable. However, regardless of $K_{\mathrm{D}}$, higher pore water concentrations imply that the risk of contaminant dispersal via pore water is elevated in fiberbanks compared to fiber-rich sediment and natural sediment for many substances (Fig. 2g-i).

When sorption was normalized to organic carbon content $\left(K_{\mathrm{TOC}}\right)$, no significant differences between sediment types were found (Fig. S6B). This is on one hand expected, considering that organic carbon is an important sorbent for hydrophobic organic contaminants, but on the other hand, it is surprising that no differences were seen as a result of the presumed differences in organic matter quality between fiberbanks and more natural sediment. However, if the contaminants found in the more natural sediment originate from particle dispersal from the fiberbanks, the contaminants may be associated will small amounts of wood fibers showing similar sorptive capacity as the wood fibers in the fiberbanks.

The sorption ( $\log K_{\mathrm{D}}$ and $\log K_{\mathrm{TOC}}$ ) was, as expected, found to be strongly correlated (Pearson, $p<0.001$ ) with the

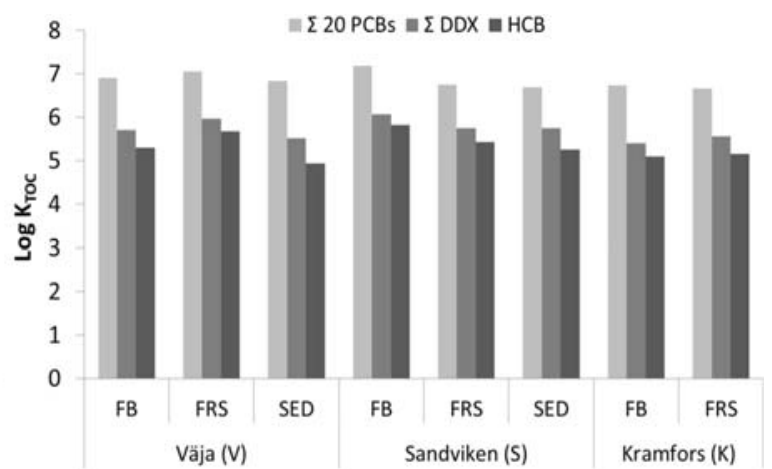

and Kramfors (K), respectively. Data are presented as geometric means. In Kramfors, only fiberbank and fiber-rich sediment samples were collected

hydrophobicity of the compounds ( $\log K_{\mathrm{OW}}$ ) as shown in Fig. S7. Comparisons of $\log K_{\mathrm{TOC}}-\log K_{\mathrm{OW}}$ correlations between sites are presented in Fig. 6, along with correlations by Seth et al. (1999), Booij et al. (2003), and Schwarzenbach et al. (2003) for more natural sediment. $\log K_{\mathrm{TOC}}-\log K_{\mathrm{OW}}$ correlations for individual sediment types are shown in Fig. S8A-C. The discrepancy between the correlations is likely, at least partly, related to the measurement techniques used. The correlations by Seth et al. (1999) and Schwarzenbach et al. (2003) are based on data compilations from previous modeling or measurement studies where methods were not optimized in distinguishing between the apparently dissolved and truly dissolved fractions in the pore water. This could lead to overestimations of the dissolved fraction and hence underestimations of the extent of sorption, and consequently, overestimations of the bioavailable fraction. The higher $\log K_{\mathrm{TOC}} \mathrm{S}$ of Booij et al. (2003), who used passive samplers (low-density polyethylene) that specifically sample the freely dissolved phase (i.e., a similar method as used in this study), is likely a consequence of the more stringent sampling method. A
Fig. 6 Relationship between sorption normalized on sediment organic carbon $\left(\log K_{\mathrm{TOC}}\right)$ and hydrophobicity $\left(\log K_{\mathrm{OW}}\right)$ of POPs in Väja (V), Sandviken (S), and Kramfors (K) for all sediment types (fiberbank, FB; fiber-rich sediment, FRS; natural sediment, SED)

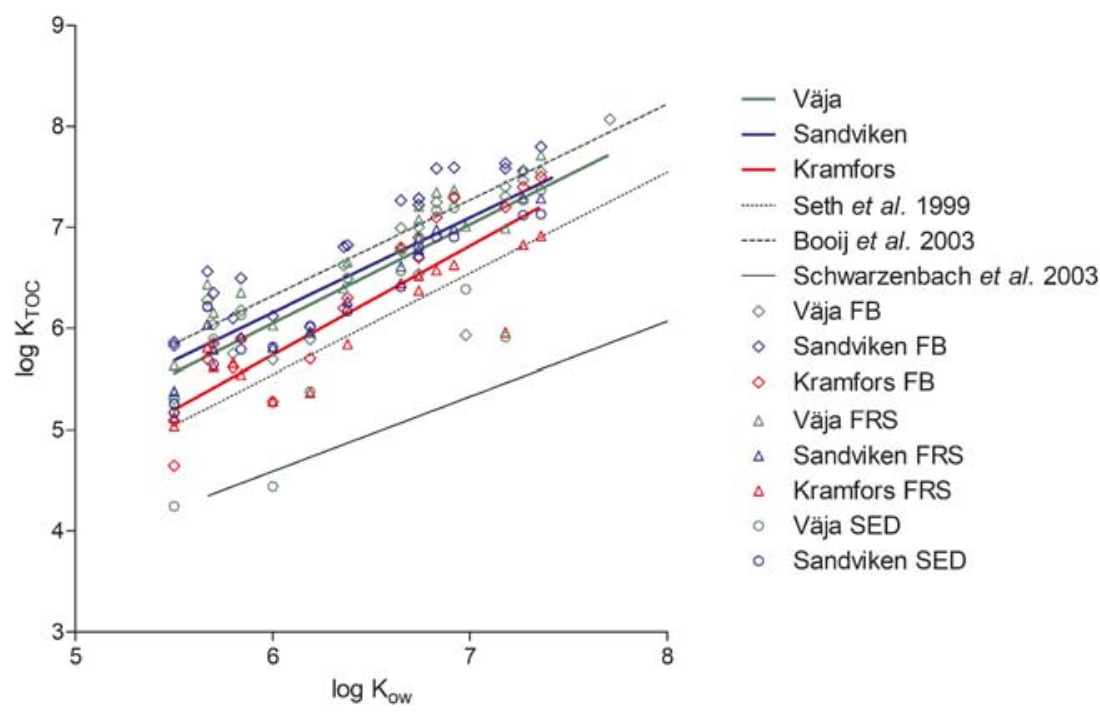


similar discrepancy between sampling methods has also been observed for PAHs (Enell et al. 2016).

For the three areas investigated in this study, the $\log K_{\mathrm{TOC}}-\log$ $K_{\text {OW }}$ correlation was best described by the equations: $\log$ $K_{\mathrm{TOC}}=0.98 \log K_{\mathrm{OW}}+0.18$ (Väja), $\log K_{\mathrm{TOC}}=0.94 \log$ $K_{\mathrm{OW}}+0.50$ (Sandviken), and $\log K_{\mathrm{TOC}}=1.1 \log K_{\mathrm{OW}}-0.73$ (Kramfors) (Fig. 6). None of the regression slopes differed significantly from Booij et al. (2003). However, the intercepts of our regression lines differed $(p<0.05)$ compared to Booij et al. (2003). It is also interesting to note that the Väja and Sandviken fiberbank slopes (Fig. S8A) did not deviate significantly from each other, despite Väja consisting of almost entirely of cellulose fibers and Sandviken mainly of wood fibers and wood chips. On the other hand, their intercepts differed significantly ( $p<0.001)$, indicating that the cellulose material may be a poorer sorbent for POPs than coarser wood material. This observation was unexpected and warrants further investigations.

\subsection{Ecotoxicological relevance}

The investigated fiberbanks are not among the most contaminated in Sweden (see Apler et al. 2014; Norrlin and Josefsson 2017), but their levels of POPs may still be detrimental to benthic organisms. A number of sediment quality guidelines (SQGs) are used around the world to assess the risks with contaminated sediments (Kwok et al. 2014). The European Union (EU) has provided technical guidance for deriving SQGs as part of its Water Framework Directive (EU-WFD 2011). EU has, however, so far derived SQGs only for a few organic compounds, none of which are included in this study. Instead, the levels reported here can be compared to SQGs from other countries, for example the revised Norwegian guidelines which largely follow the approach developed by EU.

According to Norwegian environmental quality standards, the sediment concentrations of $\Sigma_{7} \mathrm{PCBs}$ in Väja (GM: $25 \mathrm{ng} \mathrm{g}^{-1} \mathrm{dw}$ ), Sandviken (GM: $37 \mathrm{ng} \mathrm{g}^{-1} \mathrm{dw}$ ), and Kramfors (30 $\mathrm{ng} \mathrm{g}^{-1} \mathrm{dw}$ ) are classified as levels that can cause chronic effects on aquatic or sediment dwelling organisms at long-term exposure (category III, $\Sigma_{7}$ PCBs: $4.1-43 \mathrm{ng} \mathrm{g}^{-1} \mathrm{dw}$ ) (Direktoratsguppen, vanndirektivet 2018). In some fiberbank samples, the concentration of $\Sigma_{7}$ PCBs (V4: $46 \mathrm{ng} \mathrm{g}^{-1} \mathrm{dw}$ and S4: $95 \mathrm{ng} \mathrm{g}^{-1} \mathrm{dw}$ ) exceeded category III and are considered to cause acute toxic effects at short time exposure (category IV, $\Sigma_{7}$ PCBs: $43-430 \mathrm{ng} \mathrm{g}^{-1} \mathrm{dw}$ ). These levels also exceed the Canadian SQG (Interim SQG) for $\mathrm{XPCBs}$ in fresh water sediment and the Australian SQG, which are set to $34 \mathrm{ng} \mathrm{g}^{-1} \mathrm{dw}$ (Canadian Council of Ministers of the Environment 2002; Simpson et al. 2013).

For $p, p^{\prime}$-DDT and HCB, the levels in the three fiberbanks are classified as category II ( $p, p^{\prime}$-DDT: $0-6 \mathrm{ng} \mathrm{g}^{-1} \mathrm{dw}$ and $0-$ $17 \mathrm{ng} \mathrm{g}^{-1} \mathrm{dw}$ ), i.e., not having toxic effects on aquatic/ sediment organisms, according to Norwegian environmental quality standards. This can be compared to the SQGs from
Canada (Interim SQGs) and Australia where the limits are $1.2 \mathrm{ng} \mathrm{g}^{-1} \mathrm{dw}$ for $\Sigma_{2} \mathrm{DDT}, 1.4 \mathrm{ng} \mathrm{g}^{-1} \mathrm{dw}$ for $\Sigma_{2} \mathrm{DDE}$, and $3.5 \mathrm{ng} \mathrm{g}^{-1} \mathrm{dw}$ for $\Sigma_{2} \mathrm{DDD}$ (Simpson et al. 2013). Based on these assessment values, four fiberbank samples were found to exceed probable effect levels (PEL) for $\Sigma_{2} \mathrm{DDD}\left(8.5 \mathrm{ng} \mathrm{g}^{-1} \mathrm{dw}\right)$ viz. V4 (14 $\left.\mathrm{ng} \mathrm{g}^{-1} \mathrm{dw}\right), \mathrm{S} 2$ (10 ng g $\left.{ }^{-1} \mathrm{dw}\right), \mathrm{S} 3$ (8.7 $\left.\mathrm{ng} \mathrm{g}^{-1} \mathrm{dw}\right)$, and S4 (9.3 $\left.\mathrm{ng} \mathrm{g}^{-1} \mathrm{dw}\right)$.

In short, PCBs and DDD appear to be present at levels that are ecotoxicologically relevant for benthic organisms and can cause toxic effects. However, it is important to note that these SQGs are derived for sediment with a substantially lower TOC content (1\%) than recorded in fiberbank sediments. As high TOC level affects the degree of sorption of pollutants, as shown for fiber sediments in this study, the bioavailable (dissolved) fraction might be overestimated when applying these SQGs on TOCrich sediments. However, the investigated compounds have been found to bioaccumulate in benthic organisms, for example in Marenzelleria spp. and Saduria entomon collected from the same sediments as in this study (Dahlberg et al. in preparation). In addition, the investigated POPs undergo biomagnification and may thus reach higher concentrations at higher trophic levels in the Baltic Sea region (Nfon and Cousins 2007).

\section{Conclusions}

This study shows that fiberbanks, an anthropogenic sediment type, are coastal hot spots for POPs in the Baltic Sea. The TOC levels in the fiberbanks $(8.6-37 \%)$ are considerably higher than in other sediment types $(\leq 6.5 \%)$. Comparisons of POP concentrations in sediment revealed that levels are elevated in fiberbanks for PCBs and DDX, even after normalization to TOC content, indicating local sources, while levels of HCB were more even, indicating diffuse sources. Although the POPs are more strongly sorbed $\left(K_{\mathrm{D}}\right)$ to this type of very organic-rich sediment, the high pore water concentrations in fiberbanks compared to the other sediment types investigated show that the risk of contaminant dispersal via pore water is still elevated for fiberbanks. However, even if contaminant levels were lower, the fiberbanks would not be suitable habitats for benthic fauna due to the severely anoxic conditions resulting from degradation of organic matter. Given the impact these contaminated fiberbanks may have on the benthic and aquatic ecosystems, there is a need to keep addressing these contaminated sites and elucidate the risk they may pose, both to their immediate surroundings and the wider environment.

Acknowledgments The authors wish to thank the crew on S/V Ocean Surveyor for their help with the sampling.

Funding information Open access funding provided by Swedish University of Agricultural Sciences. The Swedish Research Council for Environment, Agricultural Sciences and Spatial planning (FORMAS) 
provided financial support via the research project TREASURE (project no. 214-2014-63).

Open Access This article is licensed under a Creative Commons Attribution 4.0 International License, which permits use, sharing, adaptation, distribution and reproduction in any medium or format, as long as you give appropriate credit to the original author(s) and the source, provide a link to the Creative Commons licence, and indicate if changes were made. The images or other third party material in this article are included in the article's Creative Commons licence, unless indicated otherwise in a credit line to the material. If material is not included in the article's Creative Commons licence and your intended use is not permitted by statutory regulation or exceeds the permitted use, you will need to obtain permission directly from the copyright holder. To view a copy of this licence, visit http://creativecommons.org/licenses/by/4.0/.

\section{References}

Aislabie JM, Richards NK, Boul HL (1997) Microbial degradation of DDT and its residues - a review. New Zealand J Agric Res 40: 269-282

Ali M, Sreekrishnan TR (2001) Aquatic toxicity from pulp and paper mill effluents: a review. Ad Environ Res 5:175-196

Apler A, Nyberg J, Jönsson K, Hedlund I, Heinemo S-Å, Kjellin B (2014) Fiberbanksprojektet - Kartläggning av fiberhaltiga sediment längs Västernorrlands kust. Geological Survey of Sweden, Report no. 2014:16, pp. 178

Apler A, Snowball I, Frogner-Kockum P, Josefsson S (2019) Distribution and dispersal of metals in contaminated fibrous sediments of industrial origin. Chemosphere 215:470-481

Birdwell J, Cook RL, Thibodeaux LJ (2007) Desorption kinetics of hydrophobic organic chemicals from sediment to water: a review of data and models. Environ Toxicol Chem 26:424-434

Booij K, Hoedemaker JR, Bakker JF (2003) Dissolved PCBs, PAHs, and $\mathrm{HCB}$ in pore waters and overlying waters of contaminated harbor sediments. Environ Sci Technol 37:4213-4220

Bremle G, Okla L, Larsson P (1995) Uptake of PCBs in fish in a contaminated river system: bioconcentration factors measured in the field. Environ Sci Technol 29:2010-2015

Canadian Council of Ministers of the Environment (2002) Canadian Sediment Quality Guidelines for the Protection of Aquatic Life: Summary tables. In: Canadian environmental quality guidelines, 1999, Canadian Council of Ministers of the Environment, Winnipeg

CEPI (2018) CEPI Key Statistics 2017. Confideration of european paper industries, Available via http://www.cepi.org/keystatistics2017. Accessed 15 Nov 2019

Cornelissen G, Wiberg K, Broman D, Arp HPH, Persson Y, Sundqvist K, Jonsson P (2008) Freely dissolved concentrations and sedimentwater activity ratios of PCDD/Fs and PCBs in the Open Baltic Sea. Environ Sci Technol 42:8733-8739

Direktoratsguppen, vanndirektivet (2018) Klassifisering av miljøtilstand i vann - Økologisk og kjemisk klassifiseringssystem for kystvann, grunnvann, innsjøer og elver

EFSA (2006) Opinion of the scientific panel on contaminants in the food chain on a request from the commission related to hexachlorobenzene as undesirable substance in animal feed. EFSA J 402:1-49

Endo S, Hale SE, Goss K-U, Arp HPH (2011) Equilibrium partition coefficients of diverse polar and nonpolar organic compounds to polyoxymethylene (POM) passive sampling devices. Environ Sci Technol 45:10124-10132

Enell A, Lundstedt S, Arp HPH, Josefsson S, Cornelissen G, Wik O, Kleja DB (2016) Combining leaching and passive sampling to measure the mobility and distribution between porewater, DOC, and colloids of native oxy-PAHs, N-PACs, and PAHs in historically contaminated soil. Environ Sci Technol 50:11797-11805

Erickson MD, Kaley RG II (2011) Applications of polychlorinated biphenyls. Environ Sci Pollut Res 18:135-151

EU-WFD (2011) Technical Guidance For Deriving Environmental Quality Standards, European Commission Guidance Document No. 27 , pp. 204

Farrell EP (1980) Swedish forestry - a question of balance. Irish Forest $37: 12$

Hawthorne SB, Miller DJ, Grabanski CB (2009) Measuring low picogram per litcr concentrations of freely dissolved polychlorinated biphenyls in sediment pore water using passive sampling with polyoxymethylene. Anal Chem 81:9472-9480

Helander B, Olsson A, Bignert A, Asplund L, Litzen K (2002) The role of DDE, PCB, coplanar PCB and eggshell parameters for reproduction in the white-tailed sea eagle (Haliaeetus albicilla) in Sweden. Ambio $31: 386-403$

HELCOM (2010) Ecosystem Health of the Baltic Sea 2003-2007. HELCOM initial holistic assessment, Balt. Sea Environ. Proc. No. 122

Jahnke A, Mayer P, McLachlan MS (2012) Sensitive equilibrium sampling to study polychlorinated biphenyl disposition in Baltic Sea sediment. Environ Sci Technol 46:10114-10122

Josefsson S (2017) Klassning av halter av organiska föroreningar i sediment. Geological Survey of Sweden, Report no. 2017:12, pp 14

Josefsson S, Leonardsson K, Gunnarsson JS, Wiberg K (2010) Bioturbation-driven release of buried PCBs and PBDEs from different depths in contaminated sediments. Environ Sci Technol 44: 7456-7464

Karickhoff SW, Brown DS, Scott TA (1979) Sorption of hydrophobic pollutants on natural sediments. Water Res 13:241-248

Kim KS, Hirai Y, Kato M, Urano K, Masunaga S (2004) Detailed PCB congener patterns in incinerator flue gas and commercial PCB formulations (Kanechlor). Chemosphere 55:539-553

Kwok KWH, Batley GE, Wenning JR, Zhu L, Vangheluwe M, Lee S (2014) Sediment quality guidelines: challenges and opportunities for improving sediment management. Environ Sci Pollut Res 21:17-27

Lacorte S, Latorre A, Barcelo D, Rigol A, Malmiqvist A, Welander T (2003) Organic compounds in paper-mill process waters and effluents. Trac-Trend Anal Chem 22:725-737

Lang S-C, Mayer P, Hursthouse A, Kotke D, Hand I, Schulz-Bull D, Witt G (2018) Assessing PCB pollution in the Baltic Sea - an equilibrium partitioning based study. Chemosphere 191:886-894

Mayer P, Tolls J, Hermens L, Mackay D (2003) Equilibrium sampling devices. Environ Sci Technol 37:184A-191A

Mayer P, Parkerton TF, Adams RG, Cargill JG, Gan J, Gouin T, Gschwend PM, Hawthorne SB, Helm P, Witt G, You J, Escher BI (2014) Passive sampling methods for contaminated sediments: scientific rationale supporting use of freely dissolved concentrations. Integr Environ Asses 10:197-209

Meijer SN, Ockenden WA, Sweetman A, Breivik K, Grimalt JO, Jones KC (2003) Global distribution and budget of PCBs and HCB in background surface soils: implications for sources and environmental processes. Environ Sci Technol 37:667-672

Nfon E, Cousins IT (2007) Modelling PCB bioaccumulation in a Baltic food web. Environ Pollut 148:73-82

Norrlin J, Josefsson S (2017) Förorenade fibersediment i svenska hav och sjöar. SGU report 2017:07, Geological Survey of Sweden

Qiu X, Zhu T, Yao B, Hu J, Hu S (2005) Contribution of Dicofol to the current DDT pollution in China. Environ Sci Technol 39:4385.4390

Schulz DE, Petrick G, Duinker JC (1989) Complete characterization of polychlorinated biphenyl congeners in commercial Aroclor and Clophen mixtures by multidimensional gas-chromatography electron-capture detection. Environ Sci Technol 23:852-859

Schwarzenbach RP, Gschwend PM, Imboden DM (2003) Environmental organic chemistry. Hoboken, New York 
Seth R, Mackay D, Muncke J (1999) Estimating the organic carbon partition coefficient and its variability for hydrophobic chemicals. Environ Sci Technol 33:2390-2394

Simpson SL, Batley GE, Chariton AA (2013) Revison of the ANZECC/ ARMCANZ Sediment Quality Guidelines, CSIRO Land and Water Science Report 08/07

Sobek A, Wiberg K, Sundqvist KL, Haglund P, Jonsson P, Cornelissen G (2014) Coastal sediments in the Gulf of Bothnia as a source of dissolved PCDD/Fs and PCBs to water and fish. Sci Total Environ 487:463-470

Sobek A, Sundqvist KL, Assefa AT, Wiberg K (2015) Baltic Sea sediment records: unlikely near-future declines in PCBs and HCB. Sci Total Environ 518:8-15

Suhr M, Klein G, Kourti I, Rodrigo Gonzalo M, Giner Santonja G, Roudier S, Delgado Sancho L (2015) Best aAvailable Techniques (BAT) reference document for the production of pulp, paper and board. European Commission Joint Research Centre - Institute for Prospective Technological Studies, Luxembourg: Publications Office of the European Union, pp 906

Swedish-EPA (1995) Branchkartläggningen, en översiktlig kartläggning av efterbehandlingsbehovet i Sverige, efterbehandling och sanering. Report no 4393
Turusov V, Rakitsky V, Tomatis L (2002) Dichlorodiphenyltrichloroethane (DDT): ubiquity, persistence, and risks. Environ Health Perspect 110: $125-128$

UNEP (2001) The Stockholm convention on persistent organic pollutants, Available via http://chm.pops.int/TheConvention/ThePOPs/ The12InitialPOPs/tabid/296/Default.aspx. Accessed 8 Dec 2017

US-EPA (1996) Method 3540C: Soxhlet extraction, Available via https:// www.epa.gov/hw-sw846/sw-846-test-method-3540c-soxhletextraction. Accessed 5 Nov 2019

Valsaraj KT, Verma S, Sojitra I, Reible DD, Thibodeaux LJ (1996) Diffusive transport of organic colloids from sediment beds. J Environ Eng-Asce 122:722-729

Wong F, Robson M, Diamond ML, Harrad S, Truong J (2009) Concentrations and chiral signatures of POPs in soils and sediments: a comparative urban versus rural study in Canada and UK. Chemosphere 74:404-411

Publisher's note Springer Nature remains neutral with regard to jurisdictional claims in published maps and institutional affiliations. 